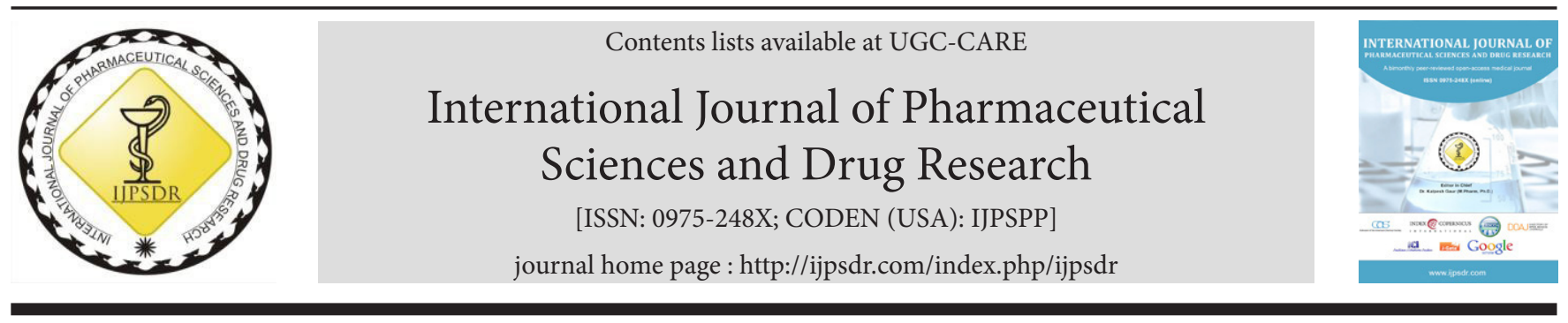

Research Article

\title{
Stability-Indicating Method Development and Validation for Simultaneous Estimation of Ombitasvir, Paritaprevir, and Ritonavir in Formulation by Ultra Performance Liquid Chromatography
}

\author{
Samudrala Lakshmi Maneka ${ }^{1 *}$, Rajaiah Thangaraj Saravanakumar ${ }^{1}$, Anjana Male ${ }^{2}$ \\ ${ }^{1}$ Department of Pharmacy, Annamalai University, Annamalai Nagar, Chidambaram-608002, Tamil Nadu, India \\ ${ }^{2}$ Department of Pharmaceutical Chemistry and Phytochemistry, Nirmala College of Pharmacy, Guntur-522503, Andhra Pradesh, India
}

\author{
A R T I C L E I N F O \\ Article history: \\ Received: 15 April, 2020 \\ Revised: 10 August, 2020 \\ Accepted: 26 August, 2020 \\ Published: 30 September, 2020 \\ Keywords: \\ Ombitasvir, Paritaprevir, \\ Ritonavir, Stability, \\ Ultra performance liquid \\ chromatography (UPLC), \\ Validation. \\ DOI: \\ 10.25004/IJPSDR.2020.120505
}

\begin{abstract}
A B S T R A C T
The present research work aimed to develop a sensitive, precise, and robust stability-indicating ultra performance liquid chromatography (UPLC) method for the simultaneous estimation of ombitasvir (OMTR), paritaprevir (PRTR), and ritonavir (RTNR) in formulations. The chromatographic separation of a mixture of OMTR, PRTR, and RTNR was attained in the isocratic method utilizing a mobile phase of $0.01 \mathrm{~N}$ potassium dihydrogen orthophosphate ( $\mathrm{pH} \mathrm{5.3)} \mathrm{and} \mathrm{methanol} \mathrm{in} \mathrm{the} \mathrm{proportion} \mathrm{of} \mathrm{60:40} \mathrm{\% v/v,} \mathrm{utilizing} \mathrm{a} \mathrm{BEH} \mathrm{C18}$ column which has dimensions of $100 \times 3 \mathrm{~mm}, 1.7 \mathrm{~m}$ particle size, and the flow rate of $0.3 \mathrm{~mL} / \mathrm{min}$. The detection system was monitored at $252 \mathrm{~nm}$ wavelength maximum with $0.2 \mathrm{~mL}$ injection volume. The retaining time for OMTR, PRTR, and RTNR was achieved at 1.765, 2.192, and 1.326 minutes, respectively. OMTR, PRTR, and RTNR and their combined drug formulation were exposed to thermal, acidic, oxidative, photolytic, and alkaline conditions. The present method was validated based on the International Council for Harmonisation (ICH) guidelines for specificity, accuracy, sensitivity, linearity, and precision. The developed method was highly sensitive, rapid, precise, and accurate than the earlier reported methods. The total run time was decreased to 3 minutes; hence, the technique was more precise and economical. Stability studies were directed for the suitability of the technique for degradation studies of OMTR, PRTR, and RTNR. The projected method can be utilized for routine analysis in the quality control department in pharmaceutical trades.
\end{abstract}

\section{INTRODUCTION}

Ombitasvir (OMTR), paritaprevir (PRTR), and ritonavir (RTNR) drugs were combined in a single dosage form (film-coated tablet) in the brand name of Technivie for the treatment of hepatitis-C. These three drugs will acts against the hepatitis-C virus (HCV) in three different mechanisms. OMTR produces its antiviral activity by inhibiting the HCV nonstructural protein (NS) 5A. OMTR chemically designated as dimethyl $([(2 \mathrm{~S}, 5 \mathrm{~S})-$ 1-(4-tert-butyl phenyl) pyrrolidine-2,5diyl] bis \{benzene -4, 1 diylcarbamoyl (2S) pyrrolidine -2, 1-diy l[(2S) -3-methyl -1-oxobutane -1, 2diyl]\}) biscarbamate hydrate with molecular weight of $894.11 \mathrm{~g} / \mathrm{mole}$ (Fig. 1). ${ }^{[1-3]}$
PRTR chemically designated as $(2 R, 6 S, 12 Z, 13$ a $S$, 14 a $R, 16$ a $S$ )- $N$-(cyclopropylsulfonyl)-6-\{[(5- methyl -2- pyrazinyl) carbonyl] amino $-5,16$-dioxo2- (6-phenanthridinyloxy) -1, 2, 3, 6, 7, 8, 9, 10, 11, 13a, 14, $15,16,16$ a -tetradecahydrocyclopropa $[e]$ pyrrolo[1,2- $a]$ $[1,4]$ diazacyclopentadecine -14 a $(5 \mathrm{H})$-carboxamide with molecular weight of $765.89 \mathrm{~g} / \mathrm{mole}$ (Fig. 1). PRTR

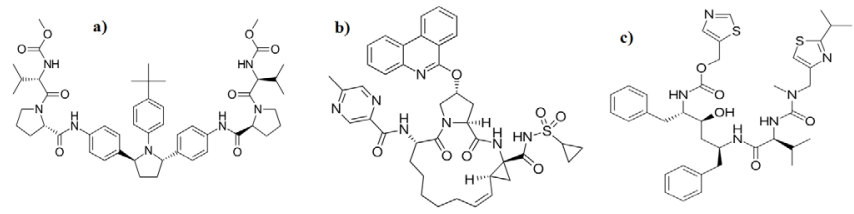

Fig. 1: Structures of a) OMTR; b) PRTR; c) RTNR

\footnotetext{
*Corresponding Author: Samudrala Lakshmi Maneka

Address: Research Scholar, Department of Pharmacy, Annamalai University, Annamalai Nagar, Chidambaram-608002, Tamil Nadu, India

Email $\square$ : dbpathi71@gmail.com

Tel.: +91-9441735710

Relevant conflicts of interest/financial disclosures: The authors declare that the research was conducted in the absence of any commercial or financial relationships that could be construed as a potential conflict of interest.

Copyright (C) 2020 Samudrala Lakshmi Maneka et al. This is an open access article distributed under the terms of the Creative Commons AttributionNonCommercial-ShareAlike 4.0 International License which allows others to remix, tweak, and build upon the work non-commercially, as long as the author is credited and the new creations are licensed under the identical terms.
} 
is powerful inhibits the NS-3/4A serine protease of HCV. Subsequently, replication of HCV genetic components and translation into a single polypeptide, NS-3, and its activating cofactor NS-4A are accountable for splitting it into the succeeding nonstructural and structural proteins essential for assembly into a mature virus, viz., NS-3, NS-4A, NS-4B, NS-5A, and NS-5B. By inhibiting viral protease NS-3/4A, PRTR, therefore, prevents viral replication and function. ${ }^{[3,4]}$

RTNR is an anti-retroviral medication utilized along with other medications to treat the human immunodeficiency virus. This combination treatment is known as highly active anti-retroviral therapy (HAART). At low doses of RTNR, it is utilized with other protease inhibiting agents and useful in combination with other hepatitis-C medicaments. It is chemically designated as 1 , 3-thiazol- 5-ylmethyl $N$-[(2S, $3 S, 5 S)$-3- hydroxy- 5-[(2S)- 3- methyl -2-\{[methyl $(\{[2-$ (propan-2-yl)-1,3-thiazol-4-yl]methyl\})carbamoyl]amino\} butanamido]-1,6-diphenylhexan-2-yl]carbamate with molecular weight of $720.946 \mathrm{~g} / \mathrm{mole}$ (Fig. 1). ${ }^{[5,6]}$

The literature review discloses that a very few liquid chromatography (LC) with tandem mass spectrometry (LC-MS/MS), ${ }^{[7]}$ high performanceliquid chromatographic, ${ }^{[8-13]}$ and spectrophotometric ${ }^{[14]}$ techniques have been reported for the estimation of OMTR, PRTR, and RTNR. Based on the reported high performance liquid chromatography (HPLC) methods, there is a need to develop a rapid, sensitive reversedphase UPLC method for simultaneous estimation of OMTR, PRTR, and RTNR, in bulk and formulations.

\section{Materials AND METhods}

\section{Chemicals and Reagents}

The standard components of OMTR, PRTR, and RTNR were provided as a gift sample from Spectrum Pharma Research Solutions, Hyderabad. Technivie tablets labeled to contain OMTR $12.5 \mathrm{mg}$, PRTR $75 \mathrm{mg}$, and RTNR $50 \mathrm{mg}$ were procured from the local market. HPLC grade methanol was obtained from A. B. Enterprises, Mumbai, India. Orthophosphoric acid was bought from Ranchem, Mumbai, India. HPLC grade water was processed by utilizing the Milli-Q Millipore water purification system used during the method development.

\section{Liquid Chromatography}

Chromatographic system of Waters UPLC system furnished with photodiode array detector, auto-sampler, and $\mathrm{BEH}$ C18 column, which have dimensions of $100 \times 3 \mathrm{~mm}, 1.7$ $m$ particle size. The output signal was monitored and integrated, utilizing water Empower-2.0 software. The isocratic mobile consisting of $0.01 \mathrm{~N}$ potassium dihydrogen orthophosphate ( $\mathrm{pH}$ 5.3) and methanol in the proportion of $60: 40 \% \mathrm{v} / \mathrm{v}$, pumped through the BEH C18 $(100 \times 3 \mathrm{~mm}$, $1.7 \mathrm{~m}$ ) column at a fixed flow of $0.3 \mathrm{~mL} / \mathrm{min}$. The injection volume of $0.2 \mathrm{~mL}$ was utilized to measure the chromatograms at $252 \mathrm{~nm}$ as the wavelength maximum in the detection system.

\section{Preparation of Buffer}

Accurately weighed 1.36 grams of potassium dihydrogen orthophosphate in a $1,000 \mathrm{~mL}$ of the volumetric flask, added about $900 \mathrm{~mL}$ of Milli-Q water added and degas to sonicate, and finally made up the volume with water. Then, $\mathrm{pH}$ adjusted to 5.3 with a dilute orthophosphoric acid solution.

\section{Preparation of Standard Stock Solution}

Accurately weighed and transferred $18.75 \mathrm{mg}$ of PRTR, $12.5 \mathrm{mg}$ of RTNR, and $3.125 \mathrm{mg}$ of OMTR working standards into a $25 \mathrm{~mL}$ clean dry volumetric flasks, added $10 \mathrm{~mL}$ of diluent, sonicated for 10 minutes, and made up to the final volume with diluent [water: methanol (50:50)] to get $750 \mu \mathrm{g} / \mathrm{mL}$ of PRTR, $500 \mu \mathrm{g} / \mathrm{mL}$ of RTNR, and $125 \mu \mathrm{g} / \mathrm{mL}$ of OMTR.

\section{Preparation of Sample Solution}

Twenty tablets were weighed and calculated the average weight of tablets, and then the weight equivalent to one tablet was transferred into a $100 \mathrm{~mL}$ volumetric flask containing $50 \mathrm{~mL}$ of diluent and sonicated for 25 minutes. Further, the volume made up with diluent and subjected for filtration by HPLC filters $(750 \mu \mathrm{g} / \mathrm{mL}$ of PRTR, $500 \mu \mathrm{g} / \mathrm{mL}$ of RTNR, and $125 \mu \mathrm{g} / \mathrm{mL}$ of OMTR). From the filtrate, $1 \mathrm{~mL}$ solution was pipetted out into a $10 \mathrm{~mL}$ volumetric flask and made up to $10 \mathrm{~mL}$ with diluent to get $75 \mu \mathrm{g} / \mathrm{mL}$ of PRTR, $50 \mu \mathrm{g} / \mathrm{mL}$ of RTNR, and $12.5 \mu \mathrm{g} / \mathrm{mL}$ of OMTR.

\section{Analytical Method Validation}

The developed method for OMTR, PRTR, and RTNR was subjected for validation for the parameters, like the limit of detection (LOD), the limit of quantification (LOQ), linearity, robustness, precision, system suitability, and accuracy as per the guidelines of ICH. ${ }^{[15-18]}$

\section{RESULTS}

\section{Optimized Chromatographic Conditions}

After systematic trials with different mobile phase compositions and other parameters involved in the technique, the following chromatographic conditions were employed:

Mobile Phase

Buffer:methanol (60:40 \%v/v)

Flow Rate

$0.3 \mathrm{~mL} / \mathrm{min}$

Column

BEH C18 $100 \times 3$ mm, $1.7 \mathrm{~m}$

Detector Wavelength

$252 \mathrm{~nm}$

Column Temperature

$30^{\circ} \mathrm{C}$ 
Injection Volume

$0.2 \mathrm{~mL}$

Run Time

3 minutes

Diluent

Water:methanol (50:50)

\section{Specificity}

It is the ability of a method to unequivocally evaluate the analyte components in the presence of other components, like impurities, degradants, and excipients, etc., expected to be present. This parameter was estimated by injecting and evaluating the blank, placebo, standard and sample solutions, and chromatograms. ${ }^{[15,16]}$ Chromatograms of blank, placebo, and sample solution shown no peaks at the retaining time of OMTR, PRTR, and RTNR peaks. The chromatograms of OMTR, PRTR, and RTNR of standard, blank, formulation, and placebo are represented in Fig. 2.

\section{Linearity}

Aliquots of $0.25,0.5,0.75,1,1.25$, and $1.5 \mathrm{~mL}$ of standard stock solution were pipetted out from the standard stock solution of concentration $750 \mu \mathrm{g} / \mathrm{mL}$ of PRTR, $500 \mu \mathrm{g} / \mathrm{mL}$ of RTNR, and $125 \mu \mathrm{g} / \mathrm{mL}$ of OMTR, and made up to $10 \mathrm{~mL}$ mark with diluent. The resulting solutions came into 18.75 to $112.5 \mu \mathrm{g} / \mathrm{mL}$ of PRTR, 12.5 to $75 \mu \mathrm{g} / \mathrm{mL}$ of RTNR, and 6.25 to $37.5 \mu \mathrm{g} / \mathrm{mL}$ of OMTR concentration range. The resulting linearity solutions were infused into a chromatographic system, and from the chromatograms, the linearity graph was plotted by taking the peak area on Y-axis and concentration on X-axis. ${ }^{[17,18]}$ The calibration graphs were shown in Table 1 and Figs 3 to 5, and all findings were within limits.

\section{System Suitability}

Six replicates of the standard reference solution were processed and infused to perform the system suitability parameter, and the resulting chromatograms peak area,
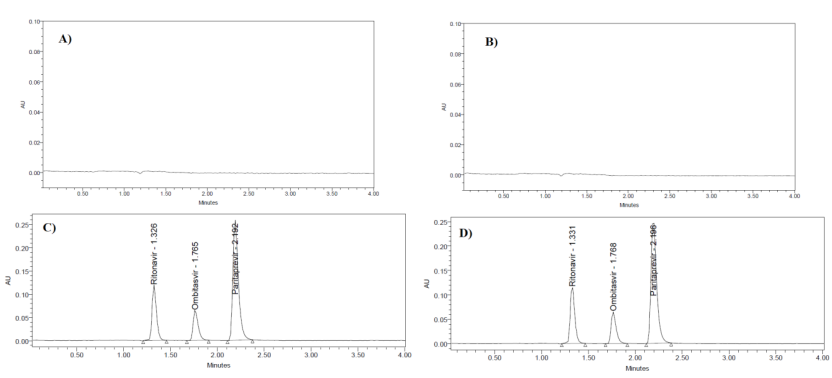

Fig. 2: Chromatograms of A) Blank; B) Placebo; C) Standard; D) Formulation

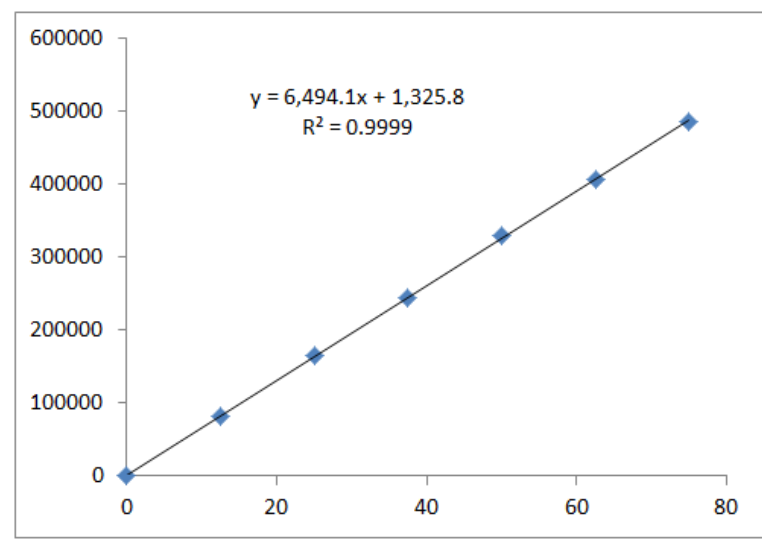

Fig. 3: Linearity of RTNR

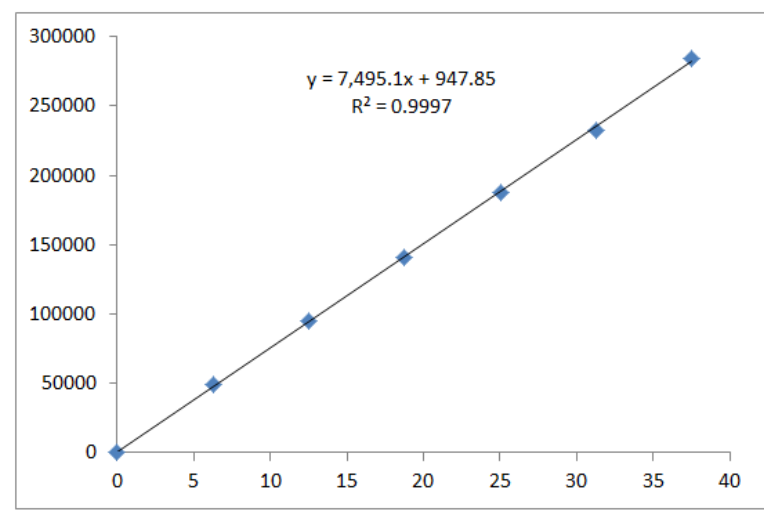

Fig. 4: Linearity of OMTR

Table 1: Calibration curve data of OMTR, PRTR, and RTNR

\begin{tabular}{|c|c|c|c|c|c|}
\hline PRTR & & RTNR & & OMTR & \\
\hline Concentration $(\mu \mathrm{g} / \mathrm{mL})$ & Peak area & Concentration $(\mu \mathrm{g} / \mathrm{mL})$ & Peak area & Concentration $(\mu \mathrm{g} / \mathrm{mL})$ & Peak area \\
\hline 18.75 & 264,180 & 12.5 & 81,636 & 6.25 & 49,632 \\
\hline 37.5 & 535,644 & 25 & 164,776 & 12.5 & 95,550 \\
\hline 56.25 & 814,159 & 37.5 & 245,348 & 18.75 & 140,564 \\
\hline 75 & $1,052,124$ & 50 & 329,483 & 25 & 187,293 \\
\hline 93.75 & $1,304,536$ & 62.5 & 406,730 & 31.25 & 232,810 \\
\hline 112.5 & $1,542,961$ & 75 & 486,017 & 37.5 & 284,512 \\
\hline \multicolumn{6}{|c|}{ Regression equation } \\
\hline \multicolumn{2}{|l|}{$y=13,764 x+13,436$} & \multicolumn{2}{|l|}{$y=6,494.1 x+1,325.8$} & \multicolumn{2}{|l|}{$y=7,495.1 x+947.85$} \\
\hline \multicolumn{6}{|c|}{ Correlation coefficient (R2) } \\
\hline 0.9993 & & 0.9999 & & 0.9997 & \\
\hline
\end{tabular}


Table 2: OMTR, PRTR, and RTNR system suitability results

\begin{tabular}{lllllll}
\hline S. No. & Peakname & Peak area & Retention time & Plate count & Resolution & Tailing \\
\hline 1. & RTNR & 322,068 & 1.331 & 3,637 & - & 1.15 \\
2. & OMTR & 196,787 & 1.783 & 5,770 & 4.9 & 1.31 \\
3. & PRTR & 903,096 & 2.212 & 7,291 & 4.2 & 1.32 \\
\hline
\end{tabular}

Table 3: Limit of detection and limit of quantification results

\begin{tabular}{llll}
\hline \multirow{2}{*}{ Parameter } & \multicolumn{3}{l}{ Measured concentration $(\mu \mathrm{g} / \mathrm{mL})$} \\
\cline { 2 - 4 } & OMTR & PRTR & RTNR \\
\hline LOD & 0.34 & 0.48 & 0.1 \\
LOQ & 1.03 & 1.44 & 0.29 \\
\hline
\end{tabular}

\begin{tabular}{llll}
\hline \multicolumn{4}{c}{ Table 4: System precision data } \\
\hline \multirow{4}{*}{ S. No. } & \multicolumn{3}{l}{ Peak area response of analytes } \\
\cline { 2 - 4 } 1 & OMTR & PRTR & RTNR \\
\hline 2 & 195,011 & 900,762 & 326,623 \\
3 & 196,240 & 908,579 & 323,604 \\
4 & 198,455 & 908,664 & 322,068 \\
5 & 196,312 & 903,595 & 323,068 \\
6 & 199,634 & 903,033 & 320,916 \\
Average & 196,787 & 903,096 & 325,455 \\
STDV & 197,073 & 904,622 & 323,022 \\
\% RSD & $1,677.8$ & $3,249.7$ & $2,117.1$ \\
\hline
\end{tabular}

STDV: Standard deviation; RSD: Relative standard deviation

Table 5: Method precision results

\begin{tabular}{llll}
\hline \multirow{4}{*}{ S. No. } & \multicolumn{3}{l}{ Peak area response ofdrugs } \\
\cline { 2 - 4 } 1 & OMTR & PRTR & RTNR \\
\hline 2 & 198,386 & 905,817 & 328,929 \\
3 & 196,022 & 905,698 & 320,925 \\
4 & 195,669 & 913,631 & 325,056 \\
5 & 196,916 & 907,149 & 323,527 \\
6 & 197,400 & 900,497 & 324,498 \\
Average & 197,831 & 901,256 & 324,874 \\
STDV & 197,037 & 905,675 & 324,635 \\
\% RSD & $1,048.6$ & $4,729.3$ & $2,595.5$ \\
\hline
\end{tabular}

STDV: Standard deviation; RSD: Relative standard deviation

retention time, resolution, plate count, and tailing were measured. The system suitability parameter findings are shown in Table 2, and related chromatograms are given in Fig. 2(C).

\section{Limit of Detection (LOD) and Limit of Quantification (LOQ)}

The LOD and LOQ parameters for OMTR, PRTR, and RTNR were calculated to form the linear regression equation. ${ }^{[16]}$ Linearity values, graphs, and regression equations were obtained from the linearity study,

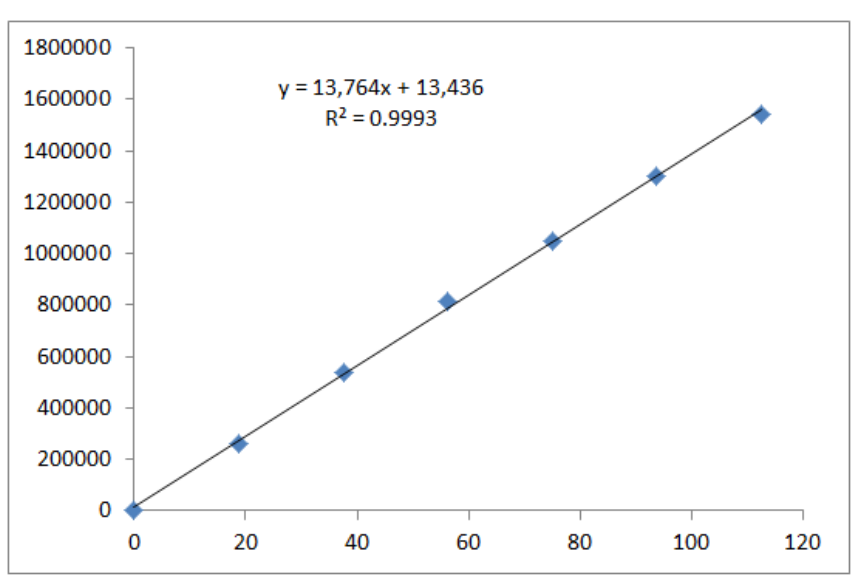

Fig. 5: Linearity of PRTR

and the LOD and LOQ values are represented in Table 3.

\section{Precision}

Analytical method precision is defined as the closeness of agreement between the replicate measurements of the analyte. It is expressed as the percentage coefficient of correlation or relative standard deviation (RSD) of the replicate measurements.

\section{System Precision}

Working standard preparation of $0.2 \mu \mathrm{L}$ solution was infused six times into the chromatographic system, and chromatograms were obtained. \% RSD of the peak area was calculated. The findings of system precision are shown in Table 4.

\section{Method Precision}

Working sample solutions of $0.2 \mu \mathrm{L}$ were infused six times into the chromatographic system, and chromatograms were obtained. The \% RSD of the assay result of six preparations was determined. The findings achieved for assay were represented in Table 5.

\section{Intermediate Precision}

Working standard preparation of $0.2 \mu \mathrm{L}$ was infused six times test preparations into the chromatographic system, and chromatograms were obtained. The \% RSD was evaluated for peak areas. The findings of the intermediate precision study are represented in Table 6.

\section{Accuracy}

A known amount of OMTR, PRTR, and RTNR at each three concentration levels of 50,100 , and $150 \%$ was added to a pre-analyzed sample solution and injected in triplicate 
at each level into the chromatographic system. ${ }^{[15,16]}$ The mean percentage recovery of OMTR, PRTR, and RTNR at each level was estimated. The findings are represented in Table 7.

\section{Robustness}

Working standard solution prepared as per test method was infused into the chromatographic system at variable conditions, such as, the flow rate at $\pm 0.1 \mathrm{~mL} / \mathrm{min}$, mobile organic phase composition by $\pm 10 \%$, and column temperature by $\pm 5^{\circ} \mathrm{C}$. The robustness study parameter results, like peak area, retention time, plate count, and tailing factor, were within limits.

Table 6: Intermediate precision results

\begin{tabular}{llll}
\hline \multirow{4}{*}{ S. No. } & \multicolumn{4}{l}{ Peak area response ofdrugs } \\
\cline { 2 - 4 } OMTR & PRTR & RTNR \\
\hline 1 & 180,926 & 862,024 & 306,500 \\
3 & 184,329 & 872,445 & 309,802 \\
4 & 181,999 & 865,006 & 300,803 \\
5 & 180,541 & 871,249 & 307,626 \\
6 & 184,666 & 864,840 & 304,839 \\
Average & 182,373 & 869,948 & 305,313 \\
STDV & $1,733.7$ & 8,027 & $3,361.3$ \\
\% RSD & 1 & 0.9 & 1.1 \\
\hline
\end{tabular}

\section{Forced Degradation Studies}

\section{Acid Degradation Studies}

To $1 \mathrm{~mL}$ of stock s solution OMTR, PRTR, and RTNR, $1 \mathrm{~mL}$ of $2 \mathrm{~N}$ hydrochloric acid was added and refluxed for 30 minutes at $60^{\circ} \mathrm{C}^{[19-21]}$ The resultant solution was diluted to obtain $750 \mu \mathrm{g} / \mathrm{mL}$ of PRTR, $500 \mu \mathrm{g} / \mathrm{mL}$ of RTNR, and $125 \mu \mathrm{g} / \mathrm{mL}$ of OMTR solution, and $0.2 \mu \mathrm{L}$ solution was injected into the chromatographic system, and the chromatograms were recorded to assess the stability of the sample (Table 8; Fig. 6).

\section{Oxidation}

To $1 \mathrm{~mL}$ of stock solution of VXR, SFR, and VLR, $1 \mathrm{~mL}$ of $20 \%$ hydrogen peroxide $\left(\mathrm{H}_{2} \mathrm{O}_{2}\right)$ was added separately. The solutions were kept for 30 minutes at $60^{\circ} \mathrm{C}$. For the UPLC study, the resultant solution was diluted to obtain

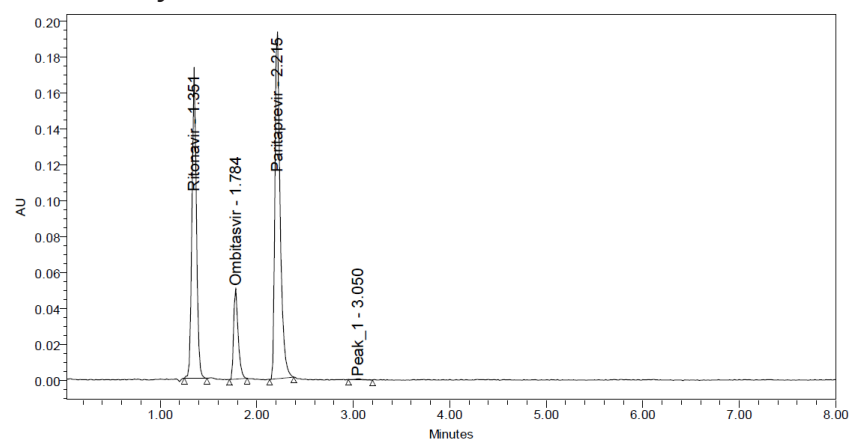

Fig. 6: Chromatogram for acid degradation study

Table 7: Percentage recovery results

\begin{tabular}{|c|c|c|c|c|c|c|c|c|c|c|c|c|}
\hline & OMTR & & & & PRTR & & & & $R T N R$ & & & \\
\hline $\begin{array}{l}\text { Spiked } \\
\text { level (\%) }\end{array}$ & $\begin{array}{l}\text { Spiked } \\
(\mu \mathrm{g} / \mathrm{mL})\end{array}$ & $\begin{array}{l}\text { Recovery } \\
(\mu \mathrm{g} / \mathrm{mL})\end{array}$ & $\begin{array}{l}\% \\
\text { recovery }\end{array}$ & $\begin{array}{l}\text { Mean \% } \\
\text { recovery }\end{array}$ & $\begin{array}{l}\text { Spiked } \\
(\mu \mathrm{g} / \mathrm{mL})\end{array}$ & $\begin{array}{l}\text { Recovery } \\
(\mu \mathrm{g} / \mathrm{mL})\end{array}$ & $\begin{array}{l}\% \\
\text { recovery }\end{array}$ & $\begin{array}{l}\text { Mean \% } \\
\text { recovery }\end{array}$ & $\begin{array}{l}\text { Spiked } \\
(\mu \mathrm{g} / \mathrm{mL})\end{array}$ & $\begin{array}{l}\text { Recovery } \\
(\mu \mathrm{g} / \mathrm{mL})\end{array}$ & $\begin{array}{l}\% \\
\text { recovery }\end{array}$ & $\begin{array}{l}\text { Mean \% } \\
\text { recovery }\end{array}$ \\
\hline \multirow[t]{3}{*}{50} & 12.5 & 12.48 & 99.8 & \multirow{6}{*}{100.19} & 37.5 & 37.25 & 99.33 & \multirow{6}{*}{99.62} & 25 & 25.32 & 101.27 & \multirow{9}{*}{99.86} \\
\hline & 12.5 & 12.56 & 100.47 & & 37.5 & 37.37 & 99.64 & & 25 & 25.17 & 100.69 & \\
\hline & 12.5 & 12.41 & 99.27 & & 37.5 & 37.38 & 99.65 & & 25 & 25.11 & 100.43 & \\
\hline \multirow[t]{3}{*}{100} & 25 & 24.87 & 99.48 & & 75 & 75.33 & 100.44 & & 50 & 50.01 & 100.02 & \\
\hline & 25 & 24.97 & 99.87 & & 75 & 74.61 & 99.48 & & 50 & 49.56 & 99.12 & \\
\hline & 25 & 25.11 & 100.45 & & 75 & 74.51 & 99.35 & & 50 & 49.76 & 99.52 & \\
\hline \multirow[t]{3}{*}{150} & 37.5 & 38.07 & 101.53 & & 112.5 & 111.95 & 99.51 & & 75 & 74.048 & 98.73 & \\
\hline & 37.5 & 37.72 & 100.6 & & 112.5 & 112.11 & 99.65 & & 75 & 74.65 & 99.54 & \\
\hline & 37.5 & 37.59 & 100.24 & & 112.5 & 111.95 & 99.51 & & 75 & 74.58 & 99.44 & \\
\hline
\end{tabular}

Table 8: Results of stress degradation study

\begin{tabular}{llllllll}
\hline & & \multicolumn{2}{l}{ PRTR } & \multicolumn{3}{l}{ OMTR } \\
\cline { 3 - 7 } S. No. & Degradation condition & \% recovery & \% degraded & \% recovery & \% degraded & \% recovery & \% degraded \\
\hline 1 & Acid hydrolysis & 93.91 & 6.09 & 92.88 & 7.12 & 86.97 & 13.03 \\
2 & Base hydrolysis & 93.99 & 6.01 & 94.7 & 5.3 & 95.92 & 4.08 \\
3 & Peroxide & 94.94 & 5.06 & 89.55 & 10.45 & 90.59 & 9.41 \\
4 & Dry heat & 97.34 & 2.66 & 96.44 & 3.56 & 97.32 & 2.68 \\
5 & Photostability & 98.78 & 1.22 & 97.43 & 2.57 & 98.62 & 1.38 \\
6 & Water sample & 99.62 & 0.38 & 99.33 & 0.67 & 99.64 & 0.36 \\
\hline
\end{tabular}


$750 \mu \mathrm{g} / \mathrm{mL}$ of PRTR, $500 \mu \mathrm{g} / \mathrm{mL}$ of RTNR, and $125 \mu \mathrm{g} / \mathrm{mL}$ of OMTR solutions, and $0.2 \mu \mathrm{L}$ solution was injected into the chromatographic system, and the chromatograms were recorded to assess the stability of sample (Table 8; Fig. 7).

\section{Alkali Degradation Studies}

To $1 \mathrm{~mL}$ of stock solution OMTR, PRTR, and RTNR, $1 \mathrm{~mL}$ of $2 \mathrm{~N}$ sodium hydroxide was added and refluxed for 30 minutes at $60^{\circ} \mathrm{C} .{ }^{[20]}$ The resultant solution was diluted to obtain $750 \mu \mathrm{g} / \mathrm{mL}$ of PRTR, $500 \mu \mathrm{g} / \mathrm{mL}$ of RTNR, and $125 \mu \mathrm{g} / \mathrm{mL}$ of OMTR, and $0.2 \mu \mathrm{L}$ solution was injected into the chromatographic system, and the chromatograms were recorded to assess the stability of sample (Table 8; Fig. 8).

\section{Dry Heat Degradation Studies}

The standard drug solution was placed in an oven at $105^{\circ} \mathrm{C}$ for 6 hours to study dry heat degradation. For the UPLC study, the resultant solution was diluted to get $750 \mu \mathrm{g} / \mathrm{mL}$ of PRTR, $500 \mu \mathrm{g} / \mathrm{mL}$ of RTNR, and $125 \mu \mathrm{g} / \mathrm{mL}$ of OMTR, and $0.2 \mu \mathrm{L}$ solution was injected into the chromatographic system. The chromatograms were recorded to assess the sample's stability (Table 8; Fig. 9).

\section{Photo Stability Studies}

The photochemical stability of the drug was also studied by exposing the $(100 \mu \mathrm{g} / \mathrm{mL}, 400 \mu \mathrm{g} / \mathrm{mL}$, and $100 \mu \mathrm{g} / \mathrm{mL})$ solution to ultra-violet (UV) light by keeping the beaker in a UV chamber for 3 days or 200 watt-hours $/ \mathrm{m}^{2}$ in photostability chamber. ${ }^{[21]}$ For the UPLC study, the resultant solution was diluted to obtain $750 \mu \mathrm{g} / \mathrm{mL}$ of PRTR, $500 \mu \mathrm{g} / \mathrm{mL}$ of RTNR, and $125 \mu \mathrm{g} / \mathrm{mL}$ of OMTR, and $0.2 \mu \mathrm{L}$ solution was injected into the chromatographic system, and the chromatograms were recorded to assess the stability of sample (Table 8; Fig. 10).

\section{Neutral Degradation Studies}

Stress testing under neutral conditions was studied by refluxing the drug in water for 6 hours at $60^{\circ} \mathrm{C}$. For the UPLC study, the resultant solution was diluted to get $750 \mu \mathrm{g} / \mathrm{mL}$ of PRTR, $500 \mu \mathrm{g} / \mathrm{mL}$ of RTNR, and $125 \mu \mathrm{g} / \mathrm{mL}$ of OMTR, and $0.2 \mu \mathrm{L}$ solution was injected into the chromatographic system. The chromatograms were recorded to assess the sample's stability (Table 8; Fig. 11).

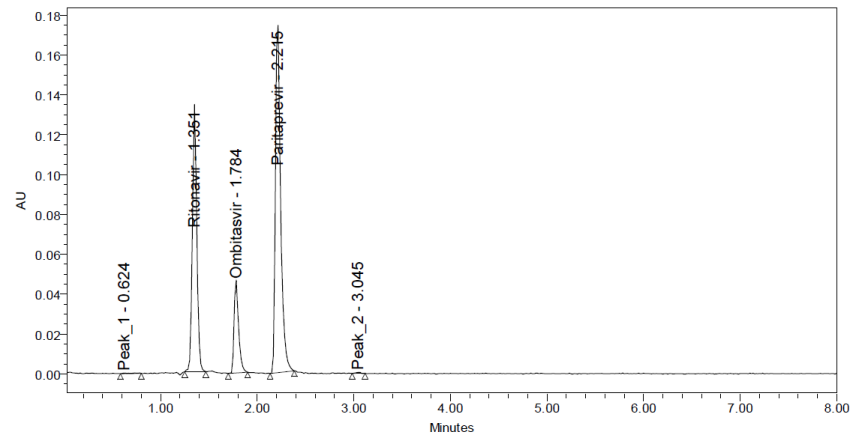

Fig. 7: Chromatogram for oxidation degradation study

\section{Assay of Marketed Formulation}

The marketed formulation of Technivie (film-coated tablet) was evaluated by infusing $0.2 \mu \mathrm{L}$ of reference and analyte solutions six times into the chromatographic system, and the resulting chromatograms of analytes were documented. The quantity of analytes that existed in the marketed formulation was estimated by equating the peak

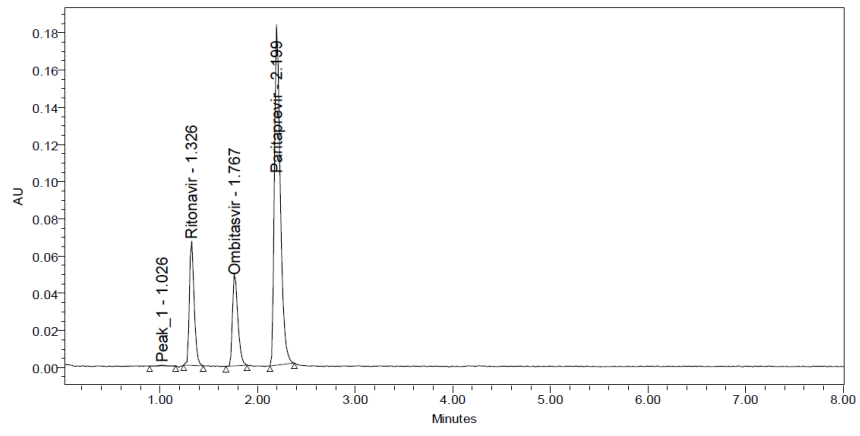

Fig. 8: Chromatogram for alkali degradation study

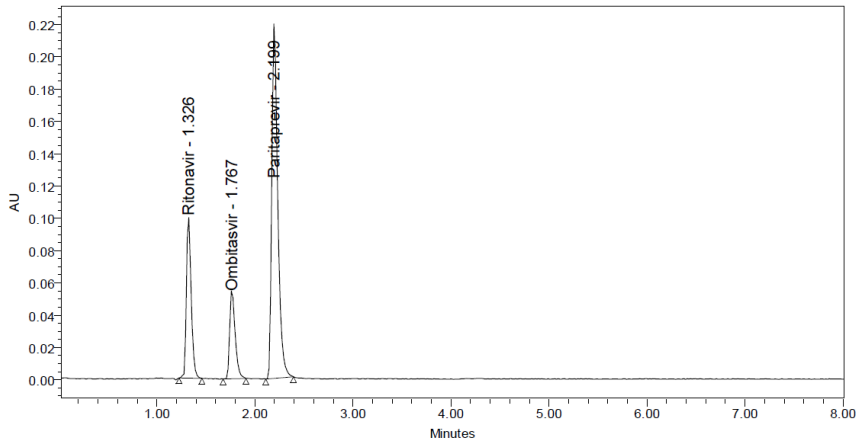

Fig. 9: Chromatogram for dry heat degradation study

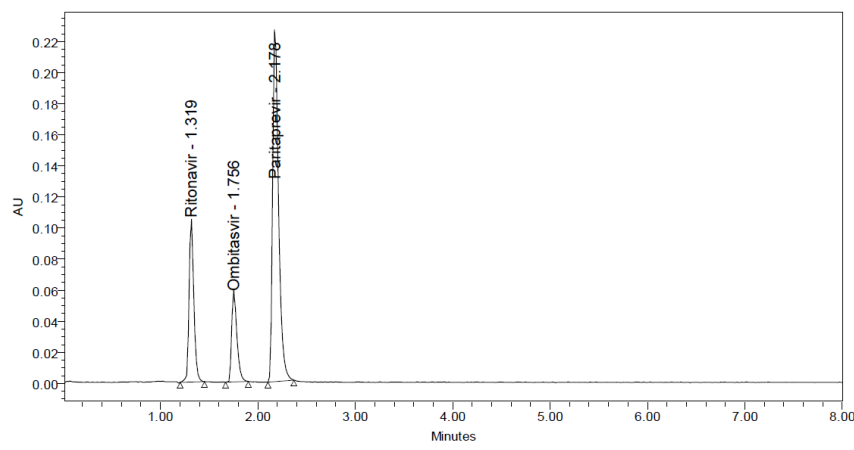

Fig. 10: Chromatogram for photostability study

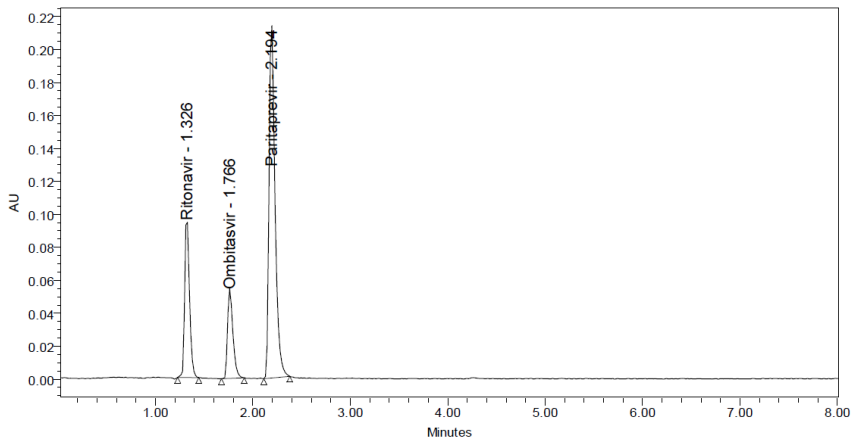

Fig. 11: Chromatogram for neutral degradation study 
area of reference and analyte. The \% assay of OMTR, PRTR, and RTNR was found to be 98.6 to $101.2 \%$.

\section{DISCUSSION}

All the methods were reported on the HPLC techniques with more retention time and run times in the literature. In the present work, we selected UPLC to reduce the total run time. Method development was executed with different columns and mobile phases. Finally, the method was optimized with a mobile phase of $0.01 \mathrm{~N}$ potassium dihydrogen orthophosphate (pH 5.3) and methanol in the proportion of $60: 40 \% \mathrm{v} / \mathrm{v}$ utilizing a BEH C18 column, which has dimensions of $100 \times 3 \mathrm{~mm}, 1.7 \mathrm{~m}$ particle size, and the flow rate of $0.3 \mathrm{~mL} / \mathrm{min}$. Further, the developed method was subjected to validation and forced degradation studies. Validation was executed as per the ICH Q2R1 guidelines for the parameters specificity, linearity, system suitability, LOD, LOQ, precision, accuracy, and robustness. All the parameters were within limits. The developed method was subjected to forced degradation studies as per the ICH, like neutral degradation, photostability, dry heat degradation, alkali degradation, oxidation, and acid degradation. The degradation results are also produced in the results section.

\section{CONCLUSION}

A sensitive, rapid, and accurate, stability-indicating RP-UPLC method for the simultaneous estimation of OMTR, PRTR, and RTNR in formulations was developed and validated as per the ICH guidelines. Retention times for OMTR, PRTR, and RTNR were achieved at 1.765, 2.192, and 1.326 minutes, respectively. The mean percentage recovery of OMTR, PRTR, and RTNR were 100.19, 99.62, and $99.86 \%$, respectively. LOD/LOQ values obtained from regression equations of OMTR, PRTR, and RTNR and were found to be $0.34 / 1.03,0.48 / 1.44$, and $0.1 / 0.29 \mu \mathrm{g} / \mathrm{mL}$, respectively. The regression equation of OMTR, PRTR, and RTNR were: $\mathrm{y}=7,495.1 \mathrm{x}+947.85, \mathrm{y}=13,764 \mathrm{x}+13,436$, and $y=6,494.1 x+1,325.8$, respectively. Stability studies of these drugs proved that the percentage of analytes' degradation was between 0.36 and $13.03 \%$. Retention time and total run times of analytes were decreased. Hence, the developed method was rapid and economical that can be applied in the routine analysis of these drugs in the quality control department of pharmaceutical trades.

\section{REFERENCES}

1. Bagaglio S, Uberti-Foppa C, Morsica G. Resistance Mechanisms in Hepatitis C Virus: implications for Direct-Acting Antiviral Use. Drugs. 2017;12:124-128.

2. Viekira Pak (Ombitasvir, Paritaprevir And Ritonavir Tablets; Dasabuvir Tablets), For Oral Use. Full Prescribing Information" (PDF). AbbVie Inc., North Chicago, IL 60064. Retrieved 30 July 2015. www. medicines.org.uk

3. Kowdley KV, Lawitz E, Poordad F, Cohen DE, Nelson DR, Zeuzem $\mathrm{S}$, et al. Phase $2 \mathrm{~b}$ trial of interferon-free therapy for hepatitis $\mathrm{C}$ virus genotype 1. N Engl J Med. 2014 Jan 16;370(3):222-32

4. Mauss, etal.,eds. (2013). Hepatology 2013 a clinical textbook(PDF) (4th ed.). Düsseldorf: Flying Publisher. ISBN 978-3-924774-90-5.

5. Papaseit E, Vázquez A, Pérez-Mañá C, Pujadas M, De La Torre R, Farré M, Nolla J. Surviving life-threatening MDMA (3,4-methylenedioxymethamphetamine, ecstasy) toxicity caused by ritonavir (RTV). Intensive Care Medicine. 2012;38 (7):1239-1240.

6. Mensing S, Eckert D, Sharma S, Polepally AR, Khatri A, Podsadecki TJ, Awni WM, Menon RM, Dutta S. Population pharmacokinetics of paritaprevir, ombitasvir, dasabuvir, ritonavir and ribavirin in hepatitis $C$ virus genotype 1 infection: analysis of six phase III trials. British J Clin Pharmacol. 2017;83: 527-539.

7. Ocque AJ, E Hagler CE, Difrancesco R, Woolwine-Cunningham Y, Bednasz CJ, Morse GD, Talal AH. Development and validation of a UPLCMS/MS method for the simultaneous determination of paritaprevir and ritonavir in rat liver. Bioanalysis. 2016;8(13):1353-1363.

8. Baje SI, Jyothi B, Madhavi N. RP-HPLC Method for simultaneous estimation of ritonavir, ombitasvir and paritaprevir in tablet dosage forms and their stress degradation studies. Int J App Pharm. 2019;11(2):193-210.

9. Wadie MA, Mostafa SM, El SM, Elgawish MS. Development and validation of a new, simple-Hplc method for simultaneous determination of ombitasvir, paritaprevir, ritonavir and ribavirin in tablet dosage form. Iosr journal of pharmacy and biological sciences. 2017;12(6): 28-35.

10. Jahnavi B, Ganapaty S. Stability indicating RP-HPLC method development and validation for the simultaneous determination of ombitasvir, paritaprevir, and ritonavir in tablet dosage forms. Asian Journal of Pharmaceutical Education and Research. 2018;7(1):90-101.

11. Al-Zoman NZ, Maher HM, Al-Subaie A. Simultaneous determination of newly developed antiviral agents in pharmaceutical formulations by HPLC-DAD. Chemistry Central Journal. 2017;11(1): 2-8.

12. Jagadeeswaran M, Gopal N, Pavan kumar K, Siva kumar T. Quantitative Estimation of Lopinavir and Ritonavir in Tablets by RP-HPLC Method Pharmaceut Anal Acta. 2012;3(5): 1-3.

13. Chiranjeevi K, Channabasavaraj KP, Lakshminarayana B, Kalyan kumar B. Development and validation of RP-HPLC method for quantitative estimation of ritonavir in bulk and pharmaceutical dosage forms. International Journal of Pharmaceutical Sciences and Research. 2011;2(2): 336-340.

14. Seetaramaiah K, Anton Smith A, Ramyateja K, Alagumanivasagam G, Manavalan R. sectrophotometric determination of ritonavir in bulk and pharmaceutical formulation. sci. Revs. Chem. Commun. 2012;2(1): 1-6.

15.ICH: Q2 (R1), validation of analytical procedures: text and methodology;2005.

16. ICH: Q2B. Harmonized Tripartite Guideline, Validation of Analytical Procedure: Methodology, IFPMA, in: Proceedings of the International Conference on Harmonization, Geneva;1996.

17. Trivedi CD, Mardia RB, Suhagia BN, Chauhan SP. Development and validation of spectrophotometric method for the estimation of ritonavir in tablet dosage form. International Journal of Pharmaceutical Sciences and Research. 2013;4(12): 4567-4572.

18. Anjaneyulu Reddy B, Irshad Alam MD, Nazia Khanam, Radha Krishnanand P. An innovative method development and forced degradation studies for simultaneous estimation of sofosbuvir and ledipasvir by RP HPLC.International Journal of Pharmacy and Pharmaceutical Sciences. 2019;11(2): 21-26.

19. ICH Guidelines Q1A (R2), Stability Testing of New Drug Substances and Products, International Conference on Harmonization;2003.

20. Ngwa G. Forced degradation studies as an integral part of HPLC stability indicating method development. Drug Delivery Technol. 2010;10:56-9.

21. Vanitha C, Reddy B, Satyanarayana SV. Quality-by-design approach to selective stability indicating RP-HPLC method development and validation of estimation of sofosbuvir in bulk drug. Int J Res Pharm Sci. 2018;9:298-308

HOW TO CITE THIS ARTICLE: Maneka SL, Saravanakumar RT, Male A. Stability-indicating method development and validation for simultaneous estimation of ombitasvir, paritaprevir, and ritonavir in formulation by ultra performance liquid chromatography. Int. J. Pharm. Sci. Drug Res. 2020;12(5):457-463. DOI: $10.25004 /$ IJPSDR.2020.120505 